\title{
Critical Wound Complication Following Major Amputation for Acute Limb Ischemia
}

\author{
Luiz-Sorin VASIU' ${ }^{1}$, Adelaida AVINO ${ }^{1,2 *}$, Daniela Elena GHEOCA-MUTU ${ }^{1,3}$, Diana-Patricia DORUS², \\ Oriana-Elena MORARU ${ }^{4}$, Cristian-Radu JECAN ${ }^{1,2}$, Laura RADUCU ${ }^{1,2}$
}

\begin{abstract}
Limb amputation has a severe somatic and psychological impact, that can furthermore have complications, which lead to increased morbidity, mortality, hospitalization days, health care costs, delay prosthetic application, and social reintegration. Proper therapeutic management must be initiated in cases with amputation stump complications to ensure the best result. This paper aims to present the therapeutic management of a patient with sepsis after above-the-knee amputation, performed after acute limb ischemia. The patient presented in our clinic 10 days postoperatively with local infection, wound dehiscence, and sepsis.
\end{abstract}

Keywords: wound dehiscence, surgical site infection, sepsis, lower limb amputation, acute limb ischemia, acute myeloid leukemia.

\section{Rezumat}

Amputația unui membru prezintă un puternic impact somatic și psihosocial, și poate fi însoțită de complicații care pot determina creșterea morbidității, a mortalității, a zilelor de spitalizare, a costurilor medicale, întârzierea protezării membrului și a integrării sociale. În cazul complicațiilor trebuie inițiat managementul terapeutic corespunzător, pentru a obține cel mai bun rezultat. Scopul acestui articol este de a prezenta managementul terapeutic al unei paciente cu sepsis după amputația deasupra genunchiului, ca urmare a ischemiei acute de membru. Pacienta s-a prezentat in clinica noastră la 10 zile postoperator cu infecție locală, dehiscența plăgii și sepsis.

Cuvinte cheie: dehiscența plăgii, infecție locală la nivelul operației, sepsis, amputație de membru inferior, ischemie acută de membru, leucemie mieloidă acută.

'Department of Plastic and Reconstructive Surgery, Emergency Clinical Hospital „Prof. Dr. Agrippa Ionescu”, Bucharest, Romania 2Discipline of Plastic and Reconstructive Surgery, "Carol Davila" University of Medicine and Pharmacy, Bucharest, Romania

3Discipline of Anatomy, "Carol Davila" University of Medicine and Pharmacy, Bucharest, Romania

${ }^{4}$ Department of Vascular Surgery, Emergency Clinical Hospital

„Prof. Dr. Agrippa Ionescu", Bucharest, Romania

\section{Corresponding author:}

Adelaida AVINO, "Carol Davila" University of Medicine and Pharmacy, 020021, Bucharest, Romania.

E-mail: adelaida.avino@gmail.com 


\section{INTRODUCTION}

The prevalence of limb amputations is considered to be $0.7 \%$ of the global population ${ }^{1}$. Limb amputations can be complicated by infection, thus increasing morbidity, health care costs, and reducing the quality of life ${ }^{2}$. The stump site presents a landscape that is prone to complications due to the synergy of many factors as amputations are a traumatic procedure for limbs` structures, combined with the patient's underlying comorbidities. Also, amputation incisions have an increased risk of complications as the amputation is more distal, given that the skin flaps ' perfusion decreases ${ }^{3}$.

Acute limb ischemia is a critical medical condition, consisting of a sudden decrease in limb perfusion, and it usually affects patients with many medical comorbidities $^{1,4}$. It can be the result of a panoply of causes: thrombotic ( $80-85 \%$ of cases), embolic (10-15\% of cases) venous obstruction, inflammatory, anatomic, iatrogenic, and trauma ${ }^{1,5,6,7}$. Urgent diagnosis, classification of the severity of limb ischemia, and appropriate treatment choice are paramount to prevent loss of limb or even life, as it has been shown in a study that in acute ischemic conditions cell damage is observed in 3 hours after the ischemic insult, and complete cell death after 6 hours ${ }^{5}$. Limb amputation is a frequent outcome, also being burdened by a high risk of infection and dehiscence $^{8}$.

Surgical site infections (SSIs) are infections affecting the deep tissues or the incision at the operation site within 30 days after surgical intervention ${ }^{9}$. Infection rates are influenced by the procedure, hospital, patients` comorbidities, but a European study suggested that SSIs rates may vary widely ranging from 1.5 $20 \%$, in European hospitals ${ }^{10}$. One study that included 38973 surgical patients, that spanned over three years, reported that $38 \%$ of deaths that occurred in patients with SSIs, were attributable to infection ${ }^{11}$.

Major limb amputation is a life-changing event, and dealing with a non-healing wound imposes additional decreases the patients' quality of life. This study aims to present the management of a complicated case of limb amputation due to acute limb ischemia in a different hospital setting, complicated with sepsis, local infection, and wound dehiscence, considering prevention strategies, risk factors, and treatment principles for complicated amputation stumps.

\section{EXPERIMENTAL - CASE PRESENTATION}

A 53-year-old female was admitted in 2019 to the Plastic Surgery Department of the „Prof. Dr. Agrippa Ionescu" Clinical and Emergency Hospital, Bucharest, with wound dehiscence, tissue necrosis, and secretions of a post-amputation thigh stump, and a post-surgical wound of the anterior right thigh and abdomen, in sepsis. The amputation was performed in another hospital 10 days before admission in our clinic, as a life-saving procedure, after a failed emergency thromboembolectomy of the Common Femoral Artery to treat acute limb ischemia. The patient's past medical history includes acute myeloid leukemia, in remission after medullar transplant, bilateral total hip arthroplasty with titanium prostheses, and an appendicectomy 14 days before the acute limb ischemia.

At admission, blood tests were performed, revealing normocytic normochromic anemia $(\mathrm{Hb}-9.7 \mathrm{~g} / \mathrm{dL}$, MCV - 96.1 Fl, MCHC - $35.8 \mathrm{~g} / \mathrm{dL})$, thrombocytosis $(527.000 / \mathrm{mL})$, leukocytosis $(13.500 / \mathrm{mL})$, high inflammation markers (C-reactive protein $(145.76 \mathrm{mg} / \mathrm{l})$, fibrinogen $(453 \mathrm{mg} / \mathrm{dL})$, erythrocyte sedimentation rate $(>140 \mathrm{~mm} / \mathrm{h}))$, hypoproteinemia $(6.3 \mathrm{~g} / \mathrm{dL})$, and electrolyte imbalance (low levels of Potassium (3.14 $\mathrm{mmol} / \mathrm{L})$ and Chloride $(100 \mathrm{mmol} / \mathrm{L})$ ).

Wound swab cultures from the dehiscent amputation stump were harvested on admission and came positive incriminating multidrug-resistant Enterococcus faecalis, Klebsiella pneumoniae, and Candida albicans as infectious pathogens.

Physical examination revealed a curvilinear-shaped postoperative wound on the anterior abdomen and right thigh, measuring approximately $25 \mathrm{~cm}$, with inflammation signs, pain, and blood drainage (Figure 1). Examination of the thigh stump revealed a postoperative dehiscent wound, painful, with necrotic tissues and foul odor (Figure 2).

The supportive and therapeutic care began. Proper hydro electrolytic equilibration therapy, antibiotic therapy with Linezolid, and Imipenem/Cilastatin, antifungal therapy with Fluconazole, anticoagulation, and pain management aimed at correcting blood test imbalances, eradicating local and systemic pathogens, and managing the patient's symptoms.

Negative pressure wound therapy was instituted for 5 days until the patient would be ready for surgery. 
Figure 1

Figure 2

Images from the physical examination of the anterior right thigh and abdomen
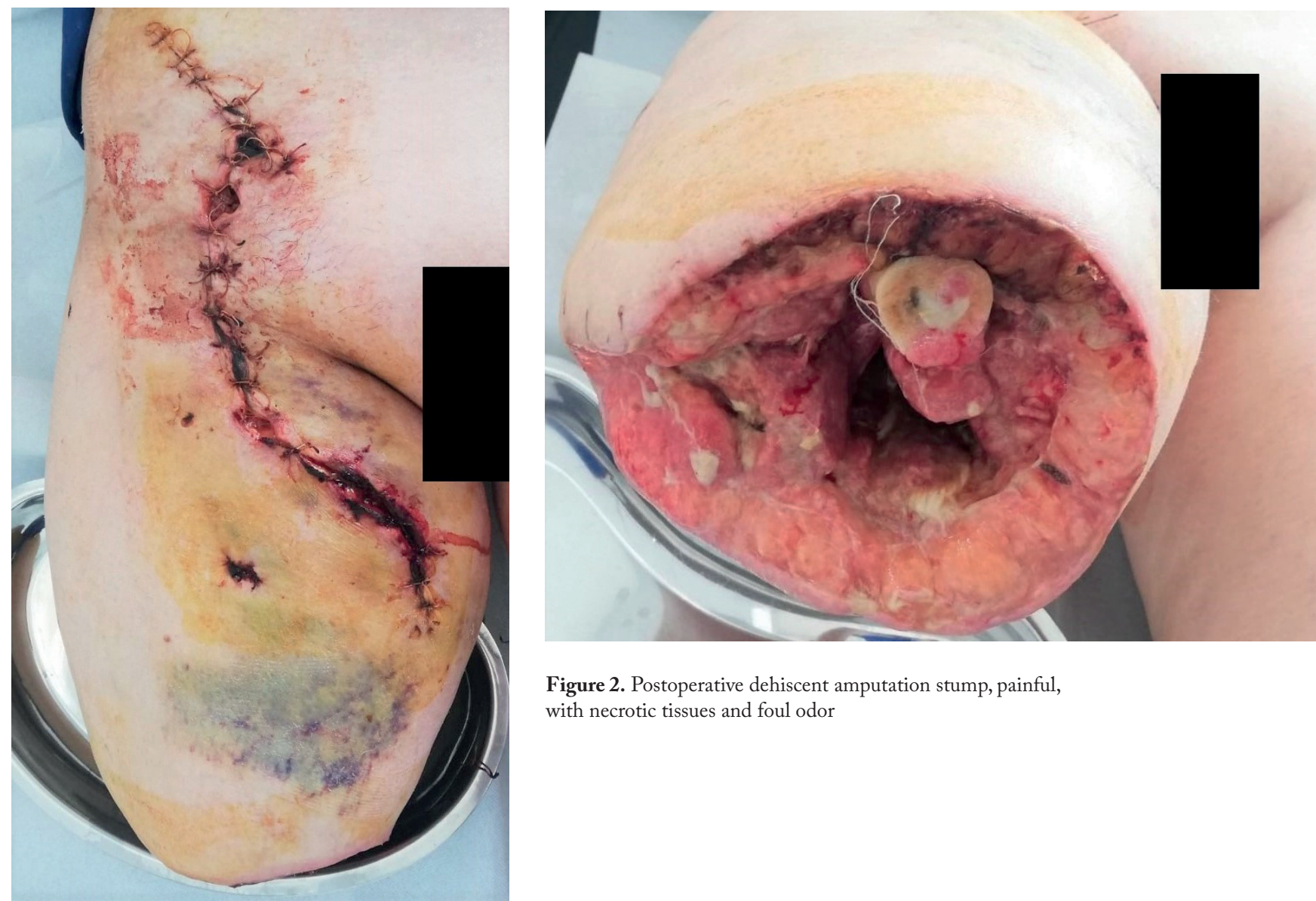

Figure 2. Postoperative dehiscent amputation stump, painful, with necrotic tissues and foul odor

Figure 1. Curvilinear shaped postoperative wound on the anterior abdomen and right thigh, measuring approximatively $25 \mathrm{~cm}$, with inflammation signs, painful, and draining blood, and from the thigh amputation stump

X-rays were taken to assess the femur, and the distance from the wound to the prostheses.

Surgical intervention was carried out on the 6th day after admission, with a multidisciplinary team (Orthopaedic Surgeon - due to the risk of prosthetic exposure, Vascular Surgeon - due to risk of vascular damage, and Plastic Surgeon - for flap coverage). On the proximal anterior thigh, the suture material was removed, revealing the Femoral Artery with a subcutaneous persistent bypass graft, and periarterial necrotic tissues. The necrotic tissues were debrided and the artery was covered with a sartorius muscle flap. The wound was closed with interrupted sutures. In the same surgical stage, the necrotic tissues of the amputation stump were debrided, osteotomy of the distal femur was carried out to allow coverage with local muscle flaps. Abundant lavage was carried out on both surgical sites. The wound was not closed at this stage. Negative pressure wound therapy was instituted at the end of the surgery.

On postoperative days 2 and 5, the wounds were lavaged and debrided under general anesthesia. On postoperative day 7 , the patient underwent the second operation, in which the necrotic tissues were excised, and after thorough lavage, the wound was partially sutured. Negative pressure wound therapy was continued until day 14.

The recovery began gradually after admission with intense medical and surgical therapy, and after 26 days the patient was discharged from the hospital with surgical closed wounds and in favorable general condition. 


\section{RESULTS AND DISCUSSION}

Although the incidence of limb amputation is lower compared to the past decades, due to increased patient education and underlying vascular and diabetic disease control, the prevalence remains high at an estimated $0.7 \%$ of the global population ${ }^{12,13,14}$. The amputation stump is prone to complications, such as infection and dehiscence, which further superimpose additional stress on the patients health and delay social reintegration $^{8}$.

A study by Hasanadka et al from 2011 identified smoking and elevated BMI as predictors for wound complications in patients with above-the-knee amputation as a complication for critical limb ischemia. Our patient had a BMI of $31 \mathrm{~kg} / \mathrm{m} 3$, and no history of smoking. The same study reports that for every increase of BMI of $10 \mathrm{~kg} / \mathrm{m} 3$, the risk of complications increases by $30 \%{ }^{15}$.

Thromboembolism of a large arterial limb vessel, with subsequent acute limb ischemia, is a possible complication of acute myeloid leukemia, as a result of the coagulopathy determined by an imbalanced interplay between procoagulant factors and anticoagulant and fibrinolytic factors ${ }^{12}$. Acute limb ischemia due to large artery thrombotic occlusion in patients with Acute Myeloid Leukemia has a rare incidence, and as such, is rarely reported in the literature ${ }^{12,16}$. Despite medical and surgical advances, limb loss rates remain high and have been observed to be proportional to the time between onset and reperfusion, with a variation between $6 \%$ if reperfusion occurs in the first 12 hours, up to $20 \%$ if reperfusion occurs after 24 hours ${ }^{17,18}$.

In a study by Dunkel et al from 2012 the infection risk for thigh stump amputation was $25 \%$, and the risk for thigh stump dehiscence was $10 \%$. The second most frequent pathogen found was Enterococcus faecalis, which was one out of three microorganisms identified in our patients' infected stump ${ }^{8}$. Wound swab cultures from the dehiscent amputation stump were harvested on admission incriminating Enterococcus faecalis, Klebsiella pneumoniae, and Candida albicans as infectious pathogens. Candida albicans is an opportunistic pathogenic yeast, that has infected our patient possibly as a consequence of a weakened immune system due to her acute myeloid leukemia, a supposition supported by an article by Mangram et al from 1999, that states that antibiotic-resistant pathogens, as an example methicillin-resistant S. Aureus or Candida albicans, may cause infection in severely ill or immunocompromised patients ${ }^{19}$. Surgical site infections also impose a great pecuniary burden on the healthcare system, increasing the economic costs of surgeries by an estimated range of $€ 1.47-19.1$ billion, as estimated in a pan-European perspective ${ }^{10,19}$.

Wound dehiscence occurs when the wound doesn't possess the structural integrity to withstand the forces it may encounter ${ }^{20}$. As a result, complete exposure of muscle and bone may occur, as in our case. Predisposing factors include infection, tissue necrosis, suture technique, ischemia, hematoma, or seroma. One way of managing a dehiscent wound is with topical Vacuum-Therapy, as it absorbs exudate, minimizing the risk of maceration, reduces the microbial burden, and it promotes granulation tissue inside the cavity wound ${ }^{21}$.

Negative pressure wound therapy has been initiated from day 1 , as studies support the idea that NPWT is beneficial in open wounds, as it promotes closure by applying pressure, removing exudate, maintaining a moist environment, and optimizing blood flow ${ }^{22,23}$. A study from Tahir et al demonstrated that NPWT reduces biofilm mass and thickness and also decreases the diffusion distances for the antimicrobial agents' penetration ${ }^{24}$. As such, NPWT has been employed in our patients` treatment preoperatively, since day 1 of her admission, and used throughout her treatment course, having a beneficial impact on wound healing.

As the majority of limb amputations are a result of ischemia, tissue necrosis due to impaired skin flap perfusion is a possible complication in this patient population. The tissues become non-viable, necrotic, and from this point, it becomes a foreign body that can become an infection core, mechanistically obstruct contraction, thus impeding wound healing ${ }^{21}$. Our case supports the previous statements, as the patients underwent amputation because of acute limb ischemia, and the devitalized tissues became an infection harboring nidus, with 3 microorganisms detected. Necrotic tissues must be removed to reduce these risks and aid wound healing. One method of debridement is the surgical one, which was employed in our case.

Surgical management was carried out following plastic surgery operative principles and the CDC guidelines for surgical site infection prevention ${ }^{25,26}$. As such, multi-stage necrotic tissue debridement and thorough lavage aimed at reducing wound bacterial burden and inhibiting biofilm formation load to relieve an overwhelmed immune system, and delayed primary 
skin closure allowing serial closure and thorough wound lavage, with the ultimate goal being wound closure.

As a result of rigorous medical and surgical therapy, 26 days after admission the patient was discharged from the hospital in favorable general condition.

\section{CONCLUSIONS}

Faced with a challenging case of a patient with a dehiscent and infected thigh amputation stump, and multiple comorbidities, the treatment must be approached by a multidisciplinary team, with rigorous medical and surgical management, in order to ensure the optimal outcome. Prevention of such complications is a priority for these patients.

\section{References}

1. McNally MM, Univers J. Acute Limb Ischemia. Surg Clin North Am. 2018 Oct;98(5):1081-1096. doi: 10.1016/j.suc.2018.05.002. PMID: 30243449

2. Dutronc H, Gobet A, Dauchy FA, Klotz R, Cazanave C, Garcia G, Lafarie-Castet S, Fabre T, Dupon M. Stump infections after major lower-limb amputation: a 10-year retrospective study. Med Mal Infect. 2013 Dec;43(11-12):456-60. doi: 10.1016/j.medmal.2013.09.003. Epub 2013 Nov 7. PMID: 24210847

3. Zayan, N. E., West, J. M., Schulz, S. A., Jordan, S. W., \& Valerio, I. L. (2019). Incisional Negative Pressure Wound Therapy: An Effective Tool for Major Limb Amputation and Amputation Revision Site Closure. Advances in wound care, 8(8), 368-373. https:// doi.org/10.1089/wound.2018.0935

4. Norgren L, Hiatt WR, Dormandy JA, et al. Inter-Society consensus for the management of peripheral arterial disease (TASC II). J Vasc Surg 2007;45(SupplS):S5-67.

5. Lindsay TF, Liauw S, Romaschin AD, Walker PM. The effect of ischemia/reperfusion on adenine nucleotide metabolism and xanthine oxidase production in skeletal muscle. J Vasc Surg. 1990 Jul;12(1):8-15. doi: 10.1067/mva.1990.19946. PMID: 2374259.

6. Ouriel K, Veith FJ, Sasahara AA. A comparison of recombinant urokinase with vascular surgery as initial treatment for acute arterial occlusion of the legs. Thrombolysis or Peripheral Arterial Surgery (TOPAS) Investigators. N EnglJMed1998;338:1105-11.

7. Ouriel K, Veith FJ, Sasahara AA. Thrombolysis or peripheral arterial surgery: phase I results. TOPAS Investigators. J Vasc Surg 1996;23:64-73 [discussion:4-5].

8. Dunkel N, Belaieff W, Assal M, Corni V, Karaca Ş, Lacraz A, Uçkay I. Wound dehiscence and stump infection after lower limb amputation: risk factors and association with antibiotic use. J Orthop Sci. 2012 Sep;17(5):588-94. doi: 10.1007/s00776-012-0245-5. Epub 2012 Jun 6. PMID: 22669444.

9. Owens CD, Stoessel K. Surgical site infections: epidemiology, microbiology and prevention. J Hosp Infect. 2008 Nov; 70 Suppl 2:3-10. doi: 10.1016/S0195-6701(08)60017-1. PMID: 19022115.

10. Leaper DJ, van Goor H, Reilly J, et al. Surgical site infection a European perspective of incidence and economic burden. Int Wound J 2004;1:247 273.
Compliance with ethics requirements: The authors declare no conflict of interest regarding this article. The authors declare that all the procedures and experiments of this study respect the ethical standards in the Helsinki Declaration of 1975, as revised in 2008(5), as well as the national law. Informed consent was obtained from all the patients included in the study.

11. Astagneau P, Rioux C, Golliot F, Brucker G for theINCISO Network Study Group. Morbidity and mortality associated with surgical site infections: results from the 1997-1999 INCISO surveillance. JHosp Infect 2001;48:267-74

12. Kharwar, R. B., Sharma, K., \& Jain, S. (2016). Acute Myeloid Leukemia with Intracardiac Thrombus Presenting as Acute Limb Ischemia. Journal of cardiovascular ultrasound, 24(2), 174-176.

13. Karakoc, A, Ersoy RU, Arslan M, Toruner FB, Yetkin I. Change in amputation rate in a Turkish diabetic foot population. J Diabetes Complicat. 2004;18:169-72.

14. Assal JP, Golay A. Patient education in Switzerland: from diabetes to chronic diseases. Patient Educ Couns. 2001;44:65-9.

15. Hasanadka R, McLafferty RB, Moore CJ, Hood DB, Ramsey DE, Hodgson KJ. Predictors of wound complications following major amputation for critical limb ischemia. J Vasc Surg. 2011 Nov;54(5):1374-82. doi: 10.1016/j.jvs.2011.04.048. Epub 2011 Aug 15. PMID: 21840153.

16. Kafetzakis A, Foundoulakis A, Ioannou CV, Stavroulaki E, Koutsopoulos A, Katsamouris AN. Acute lower limb ischemia as the initial symptom of acute myeloid leukemia. Vasc Med. 2007 Aug;12(3):199-202. doi: 10.1177/1358863X07080630. PMID: 17848476

17. Santistevan JR. Acute Limb Ischemia: An Emergency Medicine Approach. Emerg Med Clin North Am. 2017 Nov;35(4):889-909. doi: 10.1016/j.emc.2017.07.006. Epub 2017 Aug 23. PMID: 28987435.

18. Bergqvist D, Troeng T, Elfstrom J, et al. Auditing surgical outcome: ten years with the Swedish Vascular Registry-Swedvasc. The Steering Committee of Swedvasc. Eur J Surg Suppl 1998;(581):3-8.

19. Mangram AJ, Horan TC, Pearson ML, Silver LC, Jarvis WR; Hospital Infection Control Practice Advisory Committee. Guideline for prevention of surgical site infection, 1999. Infect Control Hosp Epidemiol 1999;20:247 278.

20.Perkins P. Surgical wounds. Wound dehiscence: causes and care. Nurs Stand Spec Supp/ 1992; 34: 12-14.

21. Huang C, Leavitt T, Bayer LR, Orgill DP. Effect of negative pressure wound therapy on wound healing. Curr Probl Surg. 2014 
Jul;51 (7):301-31. doi: 10.1067/j.cpsurg.2014.04.001. Epub 2014 Apr 26. PMID: 24935079.

22. Han, G., \&Ceilley, R. (2017). Chronic Wound Healing: A Review of Current Management and Treatments. Advances in therapy, 34(3), 599-610. https://doi.org/10.1007/s12325-0170478-y.

23. Avino, Adelaida\&Jecan, Cristian \& Marina, Cristina \& Daniela Gabriela, Balan \& Mihai, Andrada\&Tanase, Mihaela \&Răducu, Laura \& Ionescu, Dorin\&Andra-Elena, Balcangiu-Stroescu. (2018). Negative Pressure Wound Therapy Using Polyurethane Foam in a Patient with Necrotizing Fasciitis. 10.37358/MP.18.4.5083.

24. Tahir, S., Malone, M., Hu, H., Deva, A., \& Vickery, K. (2018). The Effect of Negative Pressure Wound Therapy with and without Instillation on Mature Biofilms In Vitro. Materials (Basel, Switzerland), 11(5), 811. https://doi.org/10.3390/ma11050811.
25. Rohrich, Rod J. M.D.; Timberlake, Andrew T. Ph.D.; Afrooz, Paul N. M.D. Revisiting the Fundamental Operative Principles of Plastic Surgery, Plastic and Reconstructive Surgery: December 2017 - Volume 140 - Issue 6 - p 1315-1318 doi: 10.1097/ PRS.0000000000003909.

26. Berríos-Torres SI, Umscheid CA, Bratzler DW, et al. Centers for Disease Control and Prevention Guideline for the Prevention of Surgical Site Infection, 2017. JAMA Surg. 2017;152(8):784-791. doi:10.1001/jamasurg.2017.0904 